\title{
AMP Student: Visão e Perspetivas
}

\author{
AMP Student: Vision and Point of View
}

Henrique CABRAL 1,2 , Pedro Câmara PESTANA ${ }^{3,4}$

Acta Med Port 2015 Mar-Apr;28(2):133-134

Palavras-chave: Estudantes de Medicina; Revistas; Portugal; Publicação.

Keywords: Periodicals as Topic; Portugal; Publishing; Students, Medical; Writing.

A escrita científica e consequente publicação assumem um papel fulcral no desenvolvimento do conhecimento científico. Um processo laborioso, preenchido de idiossincrasias metódicas e sequenciais, alastrando-se pelo largo espectro de passos que constitui a metodologia de análise de dados, seguida da análise crítica de resultados, passando pela pesquisa bibliográfica, até à reta final da redação e publicação. De metodologia bem definida, intrinsecamente trabalhosa e por vezes de desenvolvimento lenta, coadjuva-se de diversos recursos de pesquisa presentes em bibliotecas, hospitais e centros de investigação, passando pelo delineamento e planeamento do manuscrito, até à submissão do mesmo. ${ }^{1}$

A comunicação de ciência é, cada vez mais, para além de uma imposição curricular nas diversas fases de formação pós-graduada, uma necessidade. Assim depreende-se sem grande esforço a necessidade de um contacto cada vez mais precoce com a realidade da publicação.

As diversas Escolas Médicas, apesar de mais sensibilizadas para a publicação científica pelos seus estudantes, pelas crescentes necessidades de publicação e pela adoção do Processo de Bolonha com consequente adequação dos currículos, particularmente no que concerne à produção de uma tese final de mestrado, tardam em oferecer as estratégias e apoio para uma publicação de qualidade e precoce por parte dos estudantes. Notou-se que existe uma grande dificuldade no que concerne à transformação das teses finais de Mestrado em artigos suscetíveis de publicação. Este dado importante aponta para a necessidade de uma sensibilização precoce e cada vez mais urgente acerca da importância da redação científica e da necessidade de serem as próprias Escolas Médicas a incentivar a apresentação dos resultados dos trabalhos científicos da sua comunidade estudantil em congressos científicos e em revistas científicas peer reviewed. ${ }^{2}$

É nesta ótica, de incentivo à publicação científica pela comunidade estudantil e perante a constatação de que as questões que os alunos precisam discutir merecem um espaço dedicado, bem como no sentido de aproveitamento de material científico que acaba por não ser utilizado, ${ }^{3}$ que a Acta Médica Portuguesa, seguindo o exemplo de outras revistas reconhecidas, das quais o BMJ Student é o principal exemplo, decidiu desenvolver a sua nova secção, especialmente destinada à publicação científica pré-graduada, designada de AMP Student.

A AMP Student nasce então da premissa de que existem matérias nos campos clínico, científico, social, político e económico que afetam a saúde e em que os estudantes se podem pronunciar; e da influência positiva que tudo isto parece ter no desenvolvimento das futuras gerações de médicos. ${ }^{3}$

A AMP Student será regida por um Regulamento próprio, atualmente já disponível para consulta pública, e manterá a qualidade e rigor científicos que caracterizam a Acta Médica Portuguesa e considerará, tal como a sua 'congénere adulta', as submissões para publicação oriundas de qualquer país.

É assim objetivo da AMP Student o seu estabelecimento nacional e internacional como principal veículo de publicação e consulta junto da comunidade estudantil da área do conhecimento biomédico.

A publicação estará disponível, ao autor estudante de medicina, sob diferentes formatos, desde artigos de revisão destinados a abordar de forma aprofundada o estado atual do conhecimento referente a diversas áreas do conhecimento biomédico; a artigos científicos originais; a relatos de casos clínicos com justificada razão de publicação experienciados pelos estudantes; aos artigos de opinião; à imagem médica; às cartas ao editor, como um comentário a um artigo da revista ou uma pequena nota sobre um tema ou caso clínico; até ao artigo perspetiva/featured article.

É objetivo também, nesta primeira fase, estabelecer uma plataforma de encontro com as diferentes Escolas Médicas e Associações de Estudantes, bem como com os diversos Congressos Médicos Nacionais organizados por estudantes para se criar a nível nacional uma verdadeira e

1. Editor-Chefe. Acta Médica Portuguesa Student. Lisboa. Portugal.

2. Interno do Ano Comum. Hospital Distrital de Santarém. Santarém. Portugal.

3. Editor Associado. Acta Médica Portuguesa Student. Lisboa. Portugal.

4. Aluno. Faculdade de Medicina. Universidade de Lisboa. Lisboa. Portugal.

Recebido: 29 de Abril de 2015 - Aceite: 29 de Abril de 2015 | Copyright $\odot$ Ordem dos Médicos 2015 
necessária rede de comunicação de ciência pelos estudantes de medicina.

A abrir o ano de 2015, a Acta Médica Portuguesa reafirma-se mais uma vez como a revista médica portuguesa de

\section{REFERÊNCIAS}

1. Crowson MG. A crash course in medical writing for health profession students. J Cancer Educ. 2013;28:554-7.

2. Munung N, Vidal L, Ouwe-Missi-Oukem-Boyer O. Do students eventually get to publish their research findings? The case of human referência, pioneira e inovadora, através de mais esta ação vocacionada para o incentivo da publicação e comunicação de ciência pelas futuras gerações médicas.

immunodeficiency virus/acquired immunodeficiency syndrome research in Cameroon. Ann Med Health Sci Res. 2014;4:436-41.

3. Roach JO. Making our voices heard: why student journals are crucial. Croat Med J. 2001;42:67-8 
Henrique CABRAL, Pedro Câmara PESTANA

\section{AMP Student: Visão e Perspetivas}

Acta Med Port 2015:28:133-134

Publicado pela Acta Médica Portuguesa, a Revista Científica da Ordem dos Médicos

Av. Almirante Gago Coutinho, 151

1749-084 Lisboa, Portugal.

Tel: +351218428 215

E-mail: submissao@actamedicaportuguesa.com

www.actamedicaportuguesa.com

ISSN:0870-399X | e-ISSN: 1646-0758

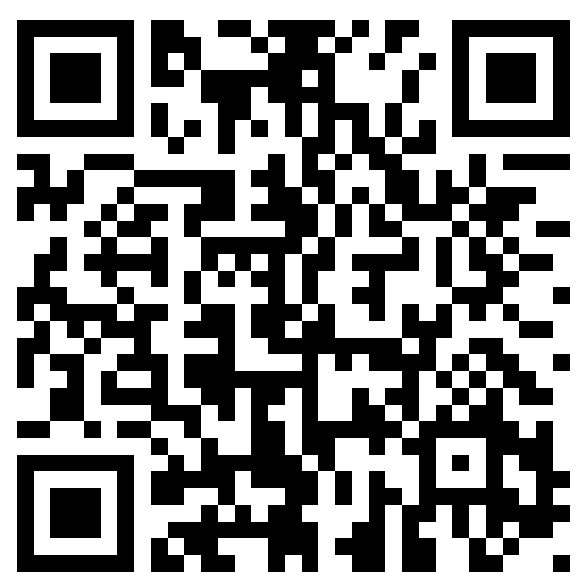

